\title{
Use of Educational Animation and Academic Performance of Business Studies Students in Akwa Ibom State
}

\author{
Paulinus J. Etim ${ }^{1}$, Atim Edet Itighise ${ }^{2}$ \& Iniobong Bassey Ema ${ }^{2, *}$ \\ ${ }^{1}$ Dept. of Educational Technology and Library Science, University of Uyo, Nigeria \\ ${ }^{2}$ Faculty of Education, Akwa Ibom State University, Ikot Akpaden, Nigeria \\ *Correspondence: Dept. of Educational Technology and Library Science, University of Uyo, \\ Nigeria. E-mail: Iniema4real@Yahoo.Com
}

Received: June 7, 2016 Accepted: June 27, 2016 Published: November 2, 2016

doi:10.5296/ije.v8i4.10259ＵRL: http://dx.doi.org/10.5296/ije.v8i4.10259

\begin{abstract}
The Study examines the use of slow-motion educational animation and academic performance of Business studies students in Akwa Ibom State. Quasi experimental non-randomized pre-test post-test design was adopted for the study. Two research questions and two hypotheses were formulated to guide the study. 88 Business education students from two schools were purposively sampled from 5146 in 13 public secondary schools in Eket Local Government Area of Akwa Ibom State-Nigeria. The subject were divided into experimental and control groups. Experimental group were treated with slow-motion educational animation while control group were taught using expository teaching method. Data were collected using Business Studies performance test (BSPT). The instrument was face and content validated by two experts, one in educational Technology and another in Measurement and Evaluation all from Faculty of Education, University of Uyo, Uyo. The instrument had reliability co-efficient of .81. The treatment was done within four weeks. The result revealed that the use of slow-motion educational animation enhance academic performance of JS 3 Business Studies students when compared to expository teaching method. It was recommended among others that teachers should use slow-motion educational animation in presentation of their lesson content for students' high academic performance and teaching effectiveness.
\end{abstract}

Keywords: use of educational animation, academic performance, business studies 


\section{Introduction}

The mode of pedagogical Strategies adopted by teachers determines the degree of learning Business Studies by the learners. Mediated instructional processes with diversified instructional resources seem to produce effective and efficient classroom Communication that produce the desired result and learning outcomes. Innovative is the key to desired behavioural moderation and manipulation. Most resources have been designed and used, Educational animations fall among the innovative resource materials that may facilitate teaching and learning.

The term "to anime" comes from the Latin word " animus" which translates into "animate", "giving life", "breath". Another meaning of the word "animus" could define animation as a reflection principle, namely "to help you think”, “to control one's emotions”. In the end, to animate means not only "to give life to the group, "but represents a specific quality of an action (Rias \& Zaman, 2011). Several studies have demonstrated positive impact of animations on understanding abstract processes. In general educational terms, animations can be viewed as a technique of visualization.

For the past two decades, the most prominent feature of the technology-based learning environment has become animation (Musa, Ziatdinov, Sozcu \& Griffiths, 2015). Computer technology allows animations to be produced much more easily and cheaply than in former years. Mayer and Moreno (2002) stated that animation is a form of pictorial presentation-a definition which also refers to computer-generated motion pictures showing associations between drawn figures. Previously, traditional animation required specialized labour-intensive techniques that were both time consuming and expensive. In contrast, software is now available that makes it possible for individual educators to author their own animations without the need for specialist expertise. Teachers are no longer limited to relying on static graphics but can readily convert them into educational animations.

Musa, Ziatdinov, Sozcu \& Griffiths (2015) comment that educational animation is a cartoon developed to be used in classrooms, on educational television programs, and in other settings where people want to provide information to people of all ages in a clear, accessible and informative way. Use of animations has been strongly encouraged as an innovative, constructive and students-centered alternative to the traditional learning approaches in many countries. Tversky \& Morrison (2002) posit that instructors can use an educational animation in the classroom during a teaching unit to provide students with a more dynamic learning experience. Animations can also make the classroom environment more interesting, capturing attention and keeping students engaged. Clark \& Mayer (2008) comment that animations help learner understand complex idea more easily. The process of teaching and learning gets a whole new experience when animations are used during the process. Both teacher and student fine it more comfortable to explain or understand a topic. It also creates long retention among learners. Research by Itighise and Ofili (2012) reported that teacher-led playlet (simulation) arouse student's interest and lead to long retention of Business Studies than expository method.

According to Tvertsky, Morrison and Betrancourt (2002) concluded that the value of animation for learning could be improved if the animations were slower and annotated with information 
to highlight the key educational features to be learned. In their opinion:

Animations must be slow and clear enough for observers to perceive movements, changes and their timing, and to understand the changes in relations between the parts and the subsequence events. This means that animations should lean toward the schematic and away from the realistic... It also may mean annotation, using arrows or highlighting or other devices to direct attention to the critical changes and relations. (p. 260)

Business Studies is a structured subject to develop the knowledge, skills and values which are necessary for learners to participate responsibly, productivity and effectively in business activities in both the formal and informal sectors. The subject investigates how private and public enterprises can be managed best to achieve profit and other objectives while providing goods and services that satisfy human needs. It also deals with how individuals, through performing critical business roles, can participate and contribute positively to Nigeria and global economies. Business studies teacher should engage learners actively by facilitating learning using group work, getting learners to talk and accommodating individual learner needs. Furthermore, the classroom layout should accommodate active learning. Experiential (i.e. active) learning, individual work, group work and continuity are essential components in the teaching of Business Studies. In experiential learning the learners get to practice skills in the classroom and reflect on these experiences.

Animation graphics are probably much better than static graphics at representing ideas which involve changes over time because of its ability to implement motion, therefore concretizing abstract temporal ideas (Rias \& Zaman, 2011). Mayer \& Moreno (2002) comment that well-designed animations help students learn faster and easier. They are also excellent aids to teachers when it comes to explaining difficult subjects. The difficulty of subjects may arise due to the involvement of mathematics or imagination. For instance, the electric current is invisible. The operation of electric circuits is difficult for students to understand at the beginning. With the aid of computer animations, teaching and learning might become easier, faster and amusing.

In spite of many research that have been done on the value of animations as tools of pedagogy, no study has yet addressed the issue of improved academic performance in Business studies. According to 2013 Junior Secondary School Certificate Examination Chief Examiner's Report, part of the problems affecting the performance of students in Business Studies could be related to the teachers' method of presenting the content of the lesson to the students. This implies that Business Studies teachers do not use appropriate instructional resources like educational animation (slow motion) to teach JSS 3 students. They tend to rely more on textbooks and verbalism which have thus far produced memory tools instead of more humane students. The study therefore, investigates if the use of educational animation (slow motion) improved academic achievement of Business Studies students in Eket Local Education Committee (LEC) of Akwa Ibom State. 


\section{Methodology}

This study is guided by Bruner J. (1966) constructivist theory. Constructivists believe more in learner constructed knowledge than they do designer-imposed instruction. This is because each person has his or her own reality. Constructivists believe learners create their own external reality, they propose a highly flexible non-hierarchical design. The theory postulates that learning is an active process in which learners construct new ideas or concepts based upon their current/past knowledge. The learner selects and transforms information, constructs hypotheses and makes decisions, relying on a cognitive structure to do so. Learning is an active process in which meaning is accomplished on the basis of experiences. This theory sees learning as being able to occur without teacher intervention once the learning resources have been constructed. In this study, the use of Educational Animation (slow motion) in the teaching-learning process of Business Studies may allow the learner to participate actively in the learning process and information processing.

The pre-test, post-test non randomized quasi experimental design was used to postulate two research questions and two research hypotheses to guide the study. The study was carried out in Eket Local Government Area of Akwa Ibom State-Nigeria. The local Government Area has 13 public secondary schools with 5146 junior secondary three students studying Business Education. This level of students takes examination to graduate into senior secondary level. The sample size of 88 students was purposively selected based on:

a) Schools have at least two qualified Business Studies students.

b) Schools with Information and Communication faculties.

Two schools were randomly selected from four schools that met the above criteria in each of the two schools, two intact classes were used, namely; the experimental and control groups were assigned. $48 \mathrm{JS} 3$ students were assigned to the experimental group and $40 \mathrm{JS} 3$ students were assigned to the control group with equal male and female in each of the groups.

Educational animation package was designed with the help of systems principles postulated by Dick and Carey (1996) and the Skinner's (1968) theory that human behaviour is interpreted as a connection between stimulus and response and that specific reaction is an exact response to a specific sensation on stimulus vis-à-vis. Educational animation package. Pre-test was conducted on the two groups to ascertain their level. The experimental groups were treated with the designed slow motion Educational Animation instructional package with their class teachers as research assistants. The exercise lasted for four weeks. The control groups were taught using the expository strategy. After the treatment, Business Studies Performance Test (BSPT) was administered to the two groups. Their scripts were marked and scores were used for analysis and comparison. The Business Studies Performance Test was face and content validated by two experts; one in the department of Educational Technology and library Science and another from Measurement and evaluation both from the Faculty of Education, University of Uyo, Uyo-Nigeria. The instrument had a reliability co-efficient of .81 using Kuder Richardson formula 21. Mean and standard deviation were used to answer the research questions while hypotheses were tested using independent t-test. 


\section{Results and Findings}

Research Question 1: What is the mean difference between the academic performance of Junior Secondary three students taught Business Studies using slow motion animation and those taught without?

Table 1. Mean and Standard Deviation of students' scores taught with slow motion animation and those taught without

\begin{tabular}{llllllll}
\hline \multirow{2}{*}{$\begin{array}{l}\text { Treatment } \\
\text { group }\end{array}$} & Gender & \multicolumn{1}{c}{ Simple } & \multicolumn{2}{c}{ Pre-test } & \multicolumn{2}{c}{ Post-test } & Mean \\
\cline { 3 - 8 } & & $\mathbf{N}$ & $\overline{\boldsymbol{X}}$ & SD & $\overline{\boldsymbol{X}}$ & SD & Diff. \\
\hline Slow motion & Male & 24 & 29.17 & 15.01 & 70.00 & 13.51 & 40.83 \\
Animation & Female & 24 & 30.47 & 11.60 & 81.70 & 11.67 & 51.23 \\
Expository & Male & 20 & 16.50 & 13.09 & 48.00 & 8.94 & 31.50 \\
Method & Female & 20 & 26.50 & 11.37 & 52.00 & 10.05 & 25.50 \\
\hline
\end{tabular}

Table 1 explains the mean gain of students taught Business Studies with slow motion Animation. The mean gain of 92.06 was higher than that of the expository group with the mean score of 56.00. This shows that students taught with Slow motion Animation perform better than those taught without Slow motion Animation.

Research Question 2: Is there any mean difference in the academic performance of Business Studies male and female students exposed to slow motion animation?

Table 2. Mean and Standard Deviation of students' scores from the Post-test Experimental Group Classify by Gender

\begin{tabular}{lllcll}
\hline $\begin{array}{l}\text { Treatment } \\
\text { group }\end{array}$ & Gender & N & $\bar{X}$ & SD & $\begin{array}{l}\text { Mean } \\
\text { Diff. }\end{array}$ \\
\hline $\begin{array}{l}\text { Slow motion } \\
\text { Animation }\end{array}$ & Male & 24 & 70.00 & 13.51 & \\
\hline
\end{tabular}

Table 2 explains male and female students mean scores taught using slow motion Animation. Female students' in the experimental group of 81.70 was seen to perform better than their male counterparts with the mean score of 70.00. Hence there is mean difference of 11.70 in the academic performance of Business Studies male and female students exposed to slow motion animation.

\section{Testing of Hypotheses}

Hypothesis I: There is no significant difference between the academic performance of Business Studies students taught using slow motion animation and those taught without. 
Table 3. t-test analysis of the difference in academic performance of students' taught using slow motion animation and those taught without

\begin{tabular}{llcllll}
\hline Treatment & N & $\overline{\boldsymbol{X}}$ & SD & df & t-cal & t-crit \\
\hline $\begin{array}{l}\text { Slow motion } \\
\text { Animation }\end{array}$ & 48 & 72.71 & 16.98 & & & \\
$\begin{array}{l}\text { Expository } \\
\text { Method }\end{array}$ & 40 & 50.25 & 9.74 & & & \\
\hline
\end{tabular}

@ $\mathrm{P}=<0.05$ level of significance

The analysis as shown on table 3 reveals that the calculated t-value of 7.77 is greater than the critical t-value of 1.99 indicating that the instructional strategies adopted had a significant effect on the academic performance of JS 3 students in Business studies. The null hypothesis is therefore rejected. This implied that, there is a significant difference in the academic performance of JS 3 Business studies students when taught using slow motion animation.

Hypothesis 2: There is no significant difference in the academic performance of male and female Business Studies students when exposed to slow motion animation.

Table 4. t-test analysis of male and female students' when exposed to slow motion animation.

\begin{tabular}{llrllll}
\hline Treatment & N & $\overline{\boldsymbol{X}}$ & SD & df & t-cal & t-crit \\
\hline Male & 24 & 70.00 & 13.51 & & & \\
& & & & 46 & $3.21^{*}$ & 2.01 \\
Female & 20 & 81.70 & 11.6 & & & \\
\hline
\end{tabular}

Results in table 4 revealed that the calculated t-value of 3.21 is greater than the critical t-value of 2.01 at 0.05 level of significance and degree of freedom 46. The hypothesis is rejected. This implied that there is a significant difference in the academic performance of male and female JS 3 students taught Business Studies using slow motion animation. Male students were seen to be highly involved in the lesson and thus had the highest effect when taught with slow motion animation.

\section{Discussion of Findings}

The study showed a significant difference between the performances of JS 3 students taught Business Studies using slow motion educational animation and taught using expository teaching method. The reason for this result is that animated pictures have cueing power, generate interest and motivate learners to learn. They are known to sustain attention and enhance learning efficiency and therefore facilitate academic performance. Use of animated pictures therefore is a strong factor and predictor of academic performance. This result is supported by the work of Clark and Mayer (2008) that animation help learners to understand complex ideas more easily. Similarly, the result is supported by the view of Itighise and Offili (2012) that teacher-led playlet (simulation) can arouse students interest and lead to long 
retention example in Business Studies than expository method.

The result also showed a significant difference in academic performances of male and female JS 3 Business studies students when taught using slow motion educational animation. The reason for this result is that male students are seen to be faster in information processing than female students. Males also can perform more stressful task than their female counterpart. The result is supported by the work of Uche \& Jephathah (2011) that there is high level educational learning aspiration among male secondary school students in Bayelsa state than female.

\section{Conclusion}

The study concludes that, Slow motion animation is the simple form of animation that is suitable for teaching abstract concepts and is highly engaging as a motivation for students in the learning process. Based on the findings of this study, it is concluded that the use of slow motion educational animation enhance academic performance of students in Business studies when compared to expository teaching method. It was also observed that male students performed better than their female counterparts when treated to slow motion animated pictures.

\section{Recommendations}

Based on the findings, the following recommendations are made to help:

1. Teachers should use slow motion educational animation in presentation of their lesson content for high academic performance and experimental or active learning.

2. Since visual served as effective communication devices with more concrete and long retention of JS 3 students, Education supervisors should ensure teachers makes use of projected materials in lesson delivery in secondary schools.

3. Workshop and seminar should be mounted by education policy makers or supervisors to teachers on the use of computer animation in the classroom environment for the purpose of supporting and improving their teaching effectiveness.

\section{References}

Bruner, J. (1966). Toward a theory of Instruction. Cambridge MA: Harvard University Press.

Clark, R. C., \& Mayer, R. E. (2008). E-learning and the Science of Instruction. San Franscisco, $\mathrm{CA}:$ Pfeiffer.

Dick, W., \& Carey, L. (1996). The systematic Design of Instruction $4^{\text {th }}$ ed. New York, NY: Harper Collins.

Itighise, A. E., \& Ofili, G. O. (2012). Teacher -led Simulation Technique and academic 
performance of Business Studies Students in Junior Secondary school in Urue-Offong/Oruku Local Government Area. Journal of Sustainable Education, 4(1), 26-33.

Mayer, R. E., \& Moreno, R. (2002). Animation as an aid to multimedia learning. Educational Psychology Review, 14, 87-99. http://dx.doi.org/10.1023/A:1013184611077

Musa, S., Ziatdinov, R., Sozcu, O., \& Griffiths, C. (2015). Developing Educational Computer Animation Based on Human Personality Types. European Journal of Contemporary Education, 11(1), 52-71. http://dx.doi.org/10.13187/ejced.2015.11.52

Rias, R. M., \& Zaman, H. B. (2011). Use of Animation in Computer-Based Instruction. Asia-Pacific Forum on Science Learning and Teaching, 12(2), Article 6.

Skinner, B. F. (1968). The Behaviour of Organisms. New York: Appleton.

Tversky B., Morrison, J. B., \& Betrancourt M. (2002). Animation: can it facilitate? International Journal of Human Computer Studies, 57, 247-262. http://dx.doi.org/10.1006/ijhc.2002.1017

Uche, C. M., \& Jephathah, H. F. (2011). Limiting Factors to Higher Educational Aspiration among Female Secondary School students in Bayelsa State. Journal of International Gender Studies, 6, 73-90.

\section{Copyright Disclaimer}

Copyright for this article is retained by the author(s), with first publication rights granted to the journal.

This is an open-access article distributed under the terms and conditions of the Creative Commons Attribution license (http://creativecommons.org/licenses/by/3.0/). 